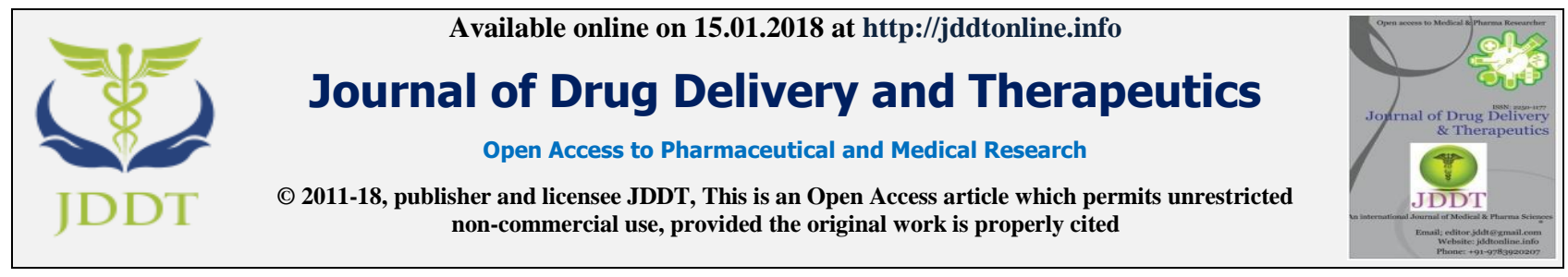

Open - Access

Research Article

\title{
MANGIFERIN PROTECTS RENAL IMPAIRMENT AGAINST BENZO (A) PYRENE INDUCED TOXICITY BY REGULATING MITOCHONDRIAL AND DNA INTEGRITY
}

\author{
Sinha Meenakshi *, Dash Deepak Kumar \\ Royal College of Pharmacy, Behind Pandit Ravishankar Shukhla University, Dumar Talab, Tatibandh PO, Raipur-492099, \\ Chhattisgarh
}

\begin{abstract}
Contaminated food and water ingestion and inhalation of polycyclic aromatic hydrocarbon are the main sources of human exposure to benzo(a)pyrene leading to cause renal injury and provoking a nephropathic response. Mangiferin is a highly potent antioxidant present in mango and known for several medicinal properties. The present study was undertaken to evaluate the renoprotective effect of mangiferin against benzo(a)pyrene induced toxicity. Benzo(a)pyrene was administered at a dose of $120.0 \mathrm{mg} / \mathrm{kg}$ once alone or in combination with mangiferin at 10.0 and $20.0 \mathrm{mg} / \mathrm{kg}$ for seven days in Swiss albino mice. Exposure to benzo(a)pyrene decreased the activities of glutathione peroxidase and increased glutathione-S-transferase level in the kidneys of mice. Moreover, DNA alkaline unwinding assay exhibit a significant decrease in F-value for the toxic control group in comparison to the normal mice, which is a marker for alteration in DNA integrity. Benzo(a)pyrene treatment also revealed an increased number of micronuclei in polychromatic erythrocytes in comparison with the control group indicating chromosomal damage in erythrocytes of bone marrow. Mangiferin pretreatment significantly improved the renal mitochondrial antioxidant status and restored the renal DNA integrity, thus demonstrating the protective effect in benzo(a)pyrene-treated mice. Dietary inclusion of mangiferin could exert protective effects against renal toxicity resulting from benzo(a)pyrene exposure.
\end{abstract}

Keywords: Benzo(a)pyrene, GPx, GST, Mangiferin, Micronucleus

Article Info: Received 23 Dec, 2017; Review Completed 10 Jan, 2018; Accepted 13 Jan, 2018; Available online 15 Jan, 2018

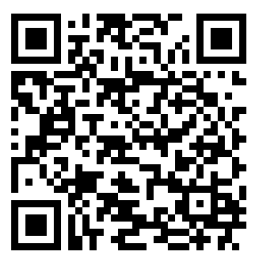

Cite this article as:

Sinha M, Dash DK, Mangiferin protects renal impairment against benzo (a) pyrene induced toxicity by regulating mitochondrial and dna integrity, Journal of Drug Delivery and Therapeutics. 2018; 8(1):92-97

DOI: http://dx.doi.org/10.22270/jddt.v8i1.1541

Dr. Meenakshi Sinha, Assistant Professor, Royal College of Pharmacy, Behind Pandit Ravishankar Shukhla University, Dumar Talab, Tatibandh PO, Raipur-492099, Chhattisgarh. Email: msinha16120@gmail.com, Phone no.: +91-9926544170

\section{INTRODUCTION}

Benzo(a)pyrene $[\mathrm{B}(\mathrm{a}) \mathrm{P}]$ is a polycyclic aromatic hydrocarbon known worldwide for its environmental contaminant property. Incomplete combustion of carbonaceous materials by humans for energy and barbeque, industrial ignition products and diesel exhaust are the chief ecological sources of $\mathrm{B}(\mathrm{a}) \mathrm{P} .^{1-3}$ The ingestion of contaminated food and water and inhalation of polycyclic aromatic hydrocarbon are the main source of human exposure to $\mathrm{B}(\mathrm{a}) \mathrm{P}$ leading to cause renal injury ${ }^{4}$ and provoking a nephropathic response. ${ }^{5}$ Nanez et al. (2005) reported renal changes in female Sprague Dawley rats following once weekly injections of 10 $\mathrm{mg} / \mathrm{kg}$ B(a)P for 16 weeks. ${ }^{6}$ Previous toxicological studies demonstrated the possible metabolic activation of $\mathrm{B}(\mathrm{a}) \mathrm{P}$ to reactive intermediates similar to the liver cells. Moreover, B(a)P-induced nephropathy was demonstrated to involve disruption of glomerular cellcell and cell-matrix interactions in rats. A single oral administration of B(a)P at the dose of $125 \mathrm{mg} / \mathrm{kg}$ caused renal toxicity and loss of DNA integrity in mice. ${ }^{7}$ Renal toxicity in rodents induced by $\mathrm{B}(\mathrm{a}) \mathrm{P}$ treatment has become popular paradigm to study protective efficacy of various novel possible therapeutic candidates.

There is considerable scientific evidence to suggest that compounds isolated from plants can inhibit the process 
of many diseases effectively. ${ }^{8}$ Xanthones are naturally synthesized in various biological systems such as plants, lichens and fungi and are stored as byproducts. In addition to taxonomic significance, they are also important in the treatment/management of a number of human disorders. Mangiferin belongs to xanthones, known as a privileged class of secondary metabolites. Initially, it was isolated primarily from the Mangifera indica but it is also present in the plants of 16 other families including Anacardiacae, Gentianaceae and Iridaceae. It is considered one of the main active constituents in more than 40 polyherbal formulations in traditional Chinese medicine. ${ }^{9}$ Mangiferin has proven its effectiveness as an antioxidant, analgesic, antidiabetic, antiproliferative, chemopreventive, radioprotective, cardiotonic, immunomodulatory and diuretic agent. It is a potent antioxidant agent and also stimulates mitochondrial respiration and suppresses oxidative and inflammation damage. ${ }^{10}$ Keeping this in mind, mangiferin was chosen to evaluate its protective effect on $\mathrm{B}(\mathrm{a}) \mathrm{P}$-induced renal toxicity. A series of indices related to oxidative stress, renal and DNA integrity were chosen to elucidate the protective effect of mangiferin on $\mathrm{B}(\mathrm{a}) \mathrm{P}$-induced toxicity in rodents to provide a means of protection against environmental $\mathrm{B}(\mathrm{a}) \mathrm{P}$-induced renal damage and to generate more comprehensive and reliable data for toxicological risk evaluation and protection by mangiferin.

\section{MATERIALS AND METHODS}

\section{Chemicals}

Genistein (purity: $\geq 98 \%$ ) and B(a)P (purity: $\geq 96 \%$ ), were purchased from Sigma-Aldrich Chemicals Pvt. Ltd., Bangalore, India. All other chemicals and reagents used were of analytical grade. Mangiferin was solubilized in $1 \%$ DMSO and $\mathrm{B}(\mathrm{a}) \mathrm{P}$ in corn oil. All other chemicals were dissolved in double distilled water. The doses for all freshly prepared drug solutions were expressed in terms of their free bases.

\section{Subjects}

Swiss albino male mice (25-30 g and 8 weeks or older) were used in this study. Animals were grouped six mice per cage and maintained at standard conditions of humidity $(55 \pm 5 \%)$, temperature $24 \pm 2{ }^{\circ} \mathrm{C}$ under $12: 12$ $\mathrm{h}$ light/dark cycle. Animals have free access to rodent chow and tap water ad libitum. Animal studies were conducted after getting approval from Institutional Animal Ethics Committee.

\section{Treatment schedule}

Animals were divided into five groups consisting six animals each.

Group I [Normal Control]: animals of this group were treated with corn oil (p.o.) for seven days.

Group II [Toxic Control]: animals of this group were administered single oral dose of B(a)P $(125.0 \mathrm{mg} / \mathrm{g})$ on the first day of experimental period to induce renotoxicity [7], followed by a single oral dose of $\mathrm{B}(\mathrm{a}) \mathrm{P}$ $(125.0 \mathrm{mg} / \mathrm{g})$ on the eighth day.
Group III [B(a)P + M (10)]: animals of this group were pretreated with mangiferin $(10.0 \mathrm{mg} / \mathrm{kg}$, i.p. $)$ for seven days, followed by a single oral dose of $\mathrm{B}(\mathrm{a}) \mathrm{P}$ (125.0 $\mathrm{mg} / \mathrm{g}$ ) on the eighth day.

Group IV [B(a)P + M (20)]: animals of this group were pretreated with mangiferin $(20.0 \mathrm{mg} / \mathrm{kg}$, i.p.) for seven days, followed by a single oral dose of $\mathrm{B}(\mathrm{a}) \mathrm{P}$ (125.0 $\mathrm{mg} / \mathrm{g}$ ) on the eighth day.

Group V [M (20)]: animals of this group were pretreated with mangiferin $(20.0 \mathrm{mg} / \mathrm{kg}$, i.p.) for seven days.

The above-mentioned doses of mangiferin were selected based on preliminary studies carried out in our laboratory. Acute and chronic toxicity studies and pharmacological studies ${ }^{11}$ conducted on mangiferin were used as reference in deriving the current doses.

\section{Assessment of mitochondrial integrity}

Post-mitochondrial supernatant and microsome preparation

Tissue processing and preparation of post-mitochondrial supernatant (PMS) were done as described by Athar and Iqbal (1998). After the treatment period, kidneys were removed quickly, cleaned free of extraneous material and immediately perfused with ice-cold saline $(0.85 \%$ sodium chloride). The kidneys were homogenized in chilled phosphate buffer $(0.1 \mathrm{M}, \mathrm{pH} 7.4)$ containing $\mathrm{KCl}$ $(1.17 \%)$ using homogenizer. The homogenate was filtered through muslin cloth and was centrifuged at 800 $\mathrm{g}$ for $5 \mathrm{~min}$ at $4{ }^{\circ} \mathrm{C}$ to separate the nuclear debris. The aliquot so obtained was centrifuged at $12000 \mathrm{rpm}$ for 20 min at $4{ }^{\circ} \mathrm{C}$ to obtain post-mitochondrial supernatant (PMS), which was used as a source of enzymes. A portion of the PMS was centrifuged for $60 \mathrm{~min}$ by ultracentrifuge at $34000 \mathrm{rpm}$ at $4{ }^{\circ} \mathrm{C}$. The pellet was washed with phosphate buffer $(0.1 \mathrm{M}, \mathrm{pH}$ 7.4) containing $\mathrm{KCl}(1.17 \%)$. All the biochemical determination were completed within $24 \mathrm{~h}$ of animal sacrifice. $^{12}$

Assay for glutathione peroxidase activity (Phase I enzyme)

Glutathione peroxidase (GPx) activity was measured by the method of Mohandas et al. (1984). The reaction mixture consisted of $1.44 \mathrm{ml}$ phosphate buffer $(0.1 \mathrm{M}$, pH 7.4), $0.1 \mathrm{ml}$ EDTA (1 mM), $0.1 \mathrm{ml}$ sodium azide (1 $\mathrm{mM}), 0.05 \mathrm{ml}$ glutathione reductase $(1 \mathrm{IU} / \mathrm{ml}), 0.05 \mathrm{ml}$ reduced glutathione $(1 \mathrm{mM}), 0.1 \mathrm{ml} \mathrm{NADPH}(0.2 \mathrm{mM})$, $0.01 \mathrm{ml} \mathrm{H}_{2} \mathrm{O}_{2}(0.25 \mathrm{mM})$ and $0.1 \mathrm{ml} 10 \%$ PMS in a total volume of $2 \mathrm{ml}$. The disappearance of NADPH at 340 $\mathrm{nm}$ was recorded at $25{ }^{\circ} \mathrm{C}$. Enzyme activity was calculated as nmol NADPH oxidized/min/mg protein using a molar extinction coefficient of $6.22 \times$ $10^{3} / \mathrm{M} / \mathrm{cm}^{13}$

\section{Assay for glutathione-S-transferase activity (Phase II enzyme)}

Glutathione-S-transferase (GST) activity was assayed by the method of Habig (1974). The reaction mixture consisted of $1.475 \mathrm{ml}$ phosphate buffer $(0.1 \mathrm{M}, \mathrm{pH} 6.5)$, $0.2 \mathrm{ml}$ reduced glutathione $(1 \mathrm{mM}), 0.025 \mathrm{ml}, 1$,chloro2, dinitrobenzene (CDNB) (1 $\mathrm{mM})$ and $0.3 \mathrm{ml}$ PMS 
$(10 \% \mathrm{w} / \mathrm{v})$ in a total volume of $2.0 \mathrm{ml}$. The changes in the absorbance were recorded at $340 \mathrm{~nm}$ and enzyme activity was calculated as nmol CDNB conjugate formed per minute per $\mathrm{mg}$ protein using a molar extinction coefficient of $9.6 \times 10^{6} / \mathrm{M} / \mathrm{cm}{ }^{14}$

\section{Assessment of DNA integrity}

\section{DNA Isolation}

DNA was extracted from approximately $500 \mathrm{mg}$ of kidney tissue by homogenizing the tissue in $5 \mathrm{ml}$ TNE buffer (50 mM Trisma, $100 \mathrm{mM}$ EDTA, 0.5\% SDS, pH 8.0 ) in a $2 \mathrm{ml}$ ground glass homogenizer. Each sample was homogenized with 10 standardized strokes of the pestle to minimize any potential effect on DNA integrity introduced by the homogenization procedure. An equal volume of buffered phenol/chloroform/isoamyl alcohol (PCI) $(25: 24: 1, \mathrm{v} / \mathrm{v} / \mathrm{v}, \mathrm{pH}$ 8.0) was then added to the sample. The sample was gently mixed and allowed to settle for $5 \mathrm{~min}$. It was then centrifuged for $5 \mathrm{~min}$ at $13000 \mathrm{rpm}$ at $4{ }^{\circ} \mathrm{C}$. The aqueous layer was transferred to a new micro centrifuge tube and PCI extraction was repeated. The aqueous layer was then digested by $5 \mathrm{ml}$ of RNAase $(10 \mathrm{mg} / \mathrm{ml})$ for $30 \mathrm{~min}$ at $37{ }^{\circ} \mathrm{C}$ and the digest was extracted once by PCI and once by $500 \mathrm{ml}$ of chloroform. DNA was precipitated from the resulting aqueous layer by adding 2 volumes of absolute ethanol and $1 / 10$ volume of $3 \mathrm{M}$ sodium acetate, $\mathrm{pH}$ 5.2. The sample was then centrifuged (13000 rpm, $15 \mathrm{~min}$ ) and the resulting pellet rinsed with $500 \mathrm{ml}$ of $70 \%$ ethanol and air-dried. The amount of DNA was quantitated spectrophotometrically at 260 and $280 \mathrm{~nm}$. Two $\mathrm{mg} / \mathrm{ml}$ of DNA sample was dissolved in $1 \mathrm{ml}$ of TE buffer (10 mM Trisma, $1 \mathrm{mM}$ EDTA) and subsequently used in the DNA alkaline unwinding assay. ${ }^{15}$

\section{Alkaline unwinding assay}

The procedure used alkaline unwinding was essentially the same as that outlined by Shugart (1988) with slight modifications. In the alkaline unwinding assay, the rate of transition of double stranded DNA (dsDNA) to single stranded DNA (ssDNA) under pre-defined alkaline denaturing condition was proportional to the number of breaks in the phosphodiester backbone and thus was used as a measure of DNA integrity. Bisbenzamide was used as a DNA-binding dye and from its fluorescence, various types of DNA were quantitated. For the fluorescence determination of dsDNA, ssDNA and partially unwound DNA (au-DNA), three equal portions of diluted DNA sample were prepared. The amount of dsDNA was obtained from the fluorescence of a sample without any treatment; while ssDNA was determined from the sample that had been boiled for $30 \mathrm{~min}$. Fluorescence of the DNA sample, which had been subjected to alkaline treatment $(\mathrm{pH} 12.2)$ on ice for 30 min provided an estimate of the amount of auDNA. The fluorescence of initial or dsDNA was determined by placing $100 \mathrm{mmol}$ DNA sample, $100 \mathrm{ml} \mathrm{NaCl}(25 \mathrm{mM})$ and $2 \mathrm{ml} \mathrm{SDS}(0.5 \%)$ in a pre-chilled test tube, followed by addition of $3 \mathrm{ml} 0.2 \mathrm{M}$ potassium phosphate $\mathrm{pH}$, and $3 \mathrm{ml}$ bisbenzamide $(1 \mathrm{mg} / \mathrm{ml})$. The contents were mixed and allowed to react in darkness for $15 \mathrm{~min}$ to allow fluorescence to stabilize. The fluorescence of the sample was measured using a spectrofluorimeter $\left(E_{\mathrm{x}}\right.$ : $\left.360 \mathrm{~nm}, \mathrm{E}_{\mathrm{m}}: 450 \mathrm{~nm}\right)$. The fluorescence of single stranded DNA was determined as above but using the DNA sample that had already been boiled for $30 \mathrm{~min}$ to completely unwinds the DNA. The amount of $0.50 \mathrm{ml}$ $\mathrm{NaOH}(0.05 \mathrm{~N})$ was rapidly mixed with $100 \mathrm{ml}$ of the DNA sample in a pre-chilled test tube. The mixture was incubated on ice in darkness for $30 \mathrm{~min} \mathrm{[15]} \mathrm{followed}$ by rapid addition and mixing of $50 \mathrm{ml} \mathrm{HCl}(0.05 \mathrm{~N})$. This was followed immediately by addition of $2 \mathrm{ml} \mathrm{SDS}$ $(0.5 \%)$ and the mixture was forcefully passed through a $21 \mathrm{G}$ needle six times. Fluorescence of alkaline unwounded DNA sample was measured as described above. Measurement of the alkaline unwounded sample was performed in triplicate and the average was reported. The ratio between dsDNA to total DNA (Fvalue) was determined as follows:

$\mathrm{F}$ value $=($ auDNA - ssDNA $) /(\operatorname{dsDNA}-$ ssDNA $)$

Where, auDNA, ssDNA and dsDNA were the degrees of fluorescence from the partially unwound, single stranded and double stranded determinations, respectively. The F value was inversely proportional to the number of strand breaks present and thus could be used as an indicator of DNA integrity. ${ }^{16}$

\section{Micronucleus test}

The mouse bone marrow micronucleus test was carried out according to the method of Schimid (1975). For this test, mice were sacrificed $24 \mathrm{~h}$ after treatment with single oral dose of B(a)P. Femur bones for bone marrow were collected for micronucleus assay and kidney tissue for enzymatic assay. The cells were smeared on glass slide, air-dried and then stained successively with MayGruenwald and Giemsa stain. Per animal, 2000 polychromatic erythrocytes (PCEs) were scored to determine the frequency of micronucleated polychromatic erythrocytes (MNPCEs) and the ratio of PCE/NCE was counted in 200 normochromatic erythrocytes (NCEs). A total of 2500-3000 polychromatic erythrocytes (PCEs) were scored per animal by the same observer for determining the frequencies of micronucleated polychromatic erythrocytes (MnPCEs). ${ }^{17}$

\section{Statistical analysis}

Differences between groups were analyzed using analysis of variance (ANOVA) followed by Tucky's multiple comparisons test. All data points are presented as the treatment groups mean \pm standard error of the mean (SEM). Probability values less than 0.05 were considered statistically significant in all the cases.

\section{RESULTS}

\section{Assessment of mitochondrial integrity}

There was a significant drop $(\mathrm{p}<0.0001)$ in levels of GPx and significant increase ( $p<0.0001)$ in GST levels in renal tissue of mice induced with $\mathrm{B}(\mathrm{a}) \mathrm{P}$ toxicity as compared to normal control mice. Chronic treatment with mangiferin (10.0 and $20.0 \mathrm{mg} / \mathrm{kg})$ followed by single dose of $\mathrm{B}(\mathrm{a}) \mathrm{P} \quad(125.0 \mathrm{mg} / \mathrm{kg})$ significantly increased $(\mathrm{p}<0.0001)$ GPx level and significantly decreased GST level $(\mathrm{p}<0.0001)$ in renal tissue compared to toxic control mice. In addition, chronic 
treatment with mangiferin alone $(20.0 \mathrm{mg} / \mathrm{kg})$ in mice significantly increased $(\mathrm{p}<0.0001)$ GPx levels and significantly decreased $(\mathrm{p}<0.0001)$ GST level in renal tissue (Table 1).

Table 1: Effect of mangiferin pretreatment on $B(a) P$ mediated alteration in glutathione peroxidase and glutathione-S-transferase enzymes

\begin{tabular}{|l|l|l|l|}
\hline Groups & Treatment & $\begin{array}{l}\text { Glutathione peroxidase } \\
\text { (nmol NADPH } \\
\text { oxidized/min/mg protein) }\end{array}$ & $\begin{array}{l}\text { Glutathione-S transferase } \\
\text { (nmol CDNB conjugate } \\
\text { formed/min/mg protein })\end{array}$ \\
\hline Normal Control & Corn oil (p.o., 7 d) & $80.32 \pm 0.59$ & $208.63 \pm 1.20$ \\
\hline Toxic Control & B(a)P (125.0 mg/g, once) & $39.81 \pm 0.21^{*}$ & $432.74 \pm 2.69^{*}$ \\
\hline B(a)P + M (10) & $\begin{array}{l}\text { Mangiferin }(10.0 \mathrm{mg} / \mathrm{kg}, \text { i.p., } 7 \mathrm{~d})+ \\
\text { B(a)P (125.0 mg/g, once) }\end{array}$ & $54.53 \pm 0.28^{\#}$ & $335.12 \pm 1.75^{\#}$ \\
\hline B(a)P + M (20) & $\begin{array}{l}\text { Mangiferin }(20.0 \mathrm{mg} / \mathrm{kg}, \text { i.p., } 7 \mathrm{~d})+ \\
\text { B(a)P (125.0 mg/g, once) }\end{array}$ & $71.86 \pm 0.40^{\#}$ & $263.39 \pm 1.44^{\#}$ \\
\hline M (20) & Mangiferin (20.0 mg/kg, i.p., 7 d) & $98.45 \pm 0.59^{\#}$ & $212.37 \pm 1.84^{\#}$ \\
\hline
\end{tabular}

Results are expressed as Mean \pm S.E.M.; $\mathrm{n}=6$ in each group. Data was analyzed by one way ANOVA followed by Tukey's test. Significance: ${ }^{*}<0.0001$ when compared with normal control group; ${ }^{*} \mathrm{p}<0.0001$ when compared with toxic control group. B(a)P: benzo(a)pyrene; M: mangiferin.

\section{Assessment of DNA integrity}

DNA alkaline unwinding assay exhibit a significant decrease $(\mathrm{p}<0.0001)$ in F-value for the toxic control group in comparison to the normal mice, which is a marker for alteration in DNA integrity. The F-value was inversely proportional to the number of strand breaks present and thus has been used as an indicator of DNA integrity. Chronic treatment with mangiferin (10.0 and $20.0 \mathrm{mg} / \mathrm{kg}$ ) followed by single dose of B(a)P (125.0 $\mathrm{mg} / \mathrm{kg}$ ) significantly increased $(\mathrm{p}<0.01$ and $\mathrm{p}<0.0001$ respectively) F-values compared to toxic control mice. In addition, chronic treatment with mangiferin alone $(20.0 \mathrm{mg} / \mathrm{kg})$ in mice significantly increased $(\mathrm{p}<0.0001)$ F-values compared to toxic control mice (Figure 1).

The effect of pretreatment of mangiferin on $\mathrm{B}(\mathrm{a}) \mathrm{P}$ induced micronuclei formation in mouse bone marrow cells has been shown in Table 2. Mangiferin treatment at both doses (10.0 and $20.0 \mathrm{mg} / \mathrm{kg})$ showed marked inhibition $(\mathrm{p}<0.0001)$ in micronuclei formation at both doses (Table 2).

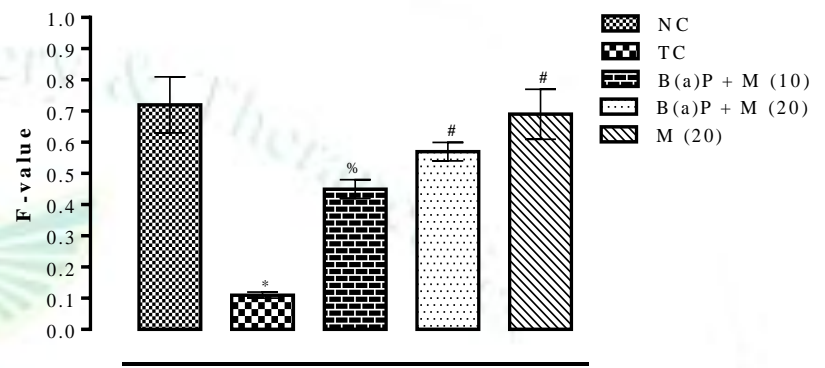

Figure 1: Effect of mangiferin pretreatment on $B(a) P$ induced DNA damage in mouse renal tissue using alkaline unwinding assay

Results are expressed as Mean \pm S.E.M.; $n=6$ in each group. Data was analyzed by one way ANOVA followed by Tukey's test. Significance: ${ }^{*} p<0.0001$ when compared with normal control group ${ }^{\%} \mathrm{p}<0.01$ when compared with toxic control group; ${ }^{*} \mathrm{p}<$ 0.0001 when compared with toxic control group. NC: normal control group, TC: toxic control group; B(a)P: benzo(a)pyrene; $\mathrm{M}$ : mangiferin.

Table 2: Effect of mangiferin pretreatment on $\mathrm{B}(\mathrm{a}) \mathrm{P}$ induced micronuclei formation in mouse bone marrow cells

\begin{tabular}{|c|c|c|c|c|c|c|}
\hline Groups & Treatment & $\begin{array}{c}\text { Number of } \\
\text { counted } \\
\text { nucleated cells }\end{array}$ & $\begin{array}{l}\text { Number } \\
\text { of PCE's }\end{array}$ & $\begin{array}{l}\text { Number of } \\
\text { PCE's with } \\
\text { micronuclei }\end{array}$ & $\begin{array}{l}\text { Percent } \\
\text { of PCE's }\end{array}$ & $\begin{array}{l}\text { Percent of } \\
\text { PCE's with } \\
\text { micronuclei }\end{array}$ \\
\hline $\begin{array}{l}\text { Normal } \\
\text { Control }\end{array}$ & Corn oil (p.o., 7 d) & 1947 & 412 & 26 & $\begin{array}{c}21.16 \pm \\
0.12 \\
\end{array}$ & $6.31 \pm 0.03$ \\
\hline $\begin{array}{l}\text { Toxic } \\
\text { Control }\end{array}$ & $\mathrm{B}(\mathrm{a}) \mathrm{P}(125.0 \mathrm{mg} / \mathrm{g}$, once $)$ & 1980 & 551 & 67 & $\begin{array}{l}27.82 \pm \\
0.34^{*}\end{array}$ & $12.15 \pm 0.06^{*}$ \\
\hline $\begin{array}{l}\mathrm{B}(\mathrm{a}) \mathrm{P}+ \\
\mathrm{M}(10)\end{array}$ & $\begin{array}{l}\text { Mangiferin }(10.0 \mathrm{mg} / \mathrm{kg}, \text { i.p., } 7 \\
\text { d) }+\mathrm{B}(\mathrm{a}) \mathrm{P}(125.0 \mathrm{mg} / \mathrm{g} \text {, once })\end{array}$ & 1893 & 463 & 42 & $\begin{array}{c}24.45 \pm \\
0.11^{\#} \\
\end{array}$ & $9.07 \pm 0.05^{\#}$ \\
\hline $\begin{array}{l}\mathrm{B}(\mathrm{a}) \mathrm{P}+ \\
\mathrm{M}(20)\end{array}$ & $\begin{array}{l}\text { Mangiferin }(20.0 \mathrm{mg} / \mathrm{kg}, \text { i.p., } 7 \\
\text { d) }+\mathrm{B}(\mathrm{a}) \mathrm{P}(125.0 \mathrm{mg} / \mathrm{g}, \text { once })\end{array}$ & 1954 & 431 & 30 & $\begin{array}{c}22.05 \pm \\
0.09^{\#} \\
\end{array}$ & $6.96 \pm 0.02^{\#}$ \\
\hline M (20) & $\begin{array}{c}\text { Mangiferin } \\
(20.0 \mathrm{mg} / \mathrm{kg}, \text { i.p., } 7 \mathrm{~d})\end{array}$ & 1966 & 406 & 24 & $\begin{array}{c}20.65 \pm \\
0.13^{\#}\end{array}$ & $5.91 \pm 0.03^{\#}$ \\
\hline
\end{tabular}

Results are expressed as Mean \pm S.E.M.; $\mathrm{n}=6$ in each group. Data was analyzed by one way ANOVA followed by Tukey's test. Significance: $" \mathrm{p}<0.0001$ when compared with normal control group; ${ }^{*} \mathrm{p}<0.0001$ when compared with toxic control group. PCEs: polychromatic erythrocytes; B(a)P: benzo(a)pyrene; M: mangiferin. 


\section{DISCUSSION}

The present study revealed that the treatment with $\mathrm{B}(\mathrm{a}) \mathrm{P}$ at the dose of $125.0 \mathrm{mg} / \mathrm{kg}$ significantly caused renal damage as assessed by monitoring mitochondrial and DNA integrity. B(a)P treatment significantly decreased GPx level and increased GST level in renal tissue. In addition, DNA alkaline unwinding assay exhibit a significant decrease in F-value and increased micronuclei formation in the $\mathrm{B}(\mathrm{a}) \mathrm{P}$ treated group. Pretreatment with mangiferin restored all the impaired conditions.

$\mathrm{B}(\mathrm{a}) \mathrm{P}$ is the most commonly studied mutagen with sources of exposure including occupation, diet and tobacco smoke. Our observations clearly indicate a compromised antioxidant defense system, inflammation and a state of oxidative stress in the renal tissues of $\mathrm{B}(\mathrm{a}) \mathrm{P}$-exposed mice. The present observations are in agreement with the previous reports that $\mathrm{B}(\mathrm{a}) \mathrm{P}$ exposure induced oxidative stress and inflammation in rodents. ${ }^{18}$ The covalent binding of carcinogens to DNA is an important step in the cancer initiation process, with $\mathrm{B}(\mathrm{a}) \mathrm{P}$ requiring metabolic activation for DNA adduct formation to occur. ${ }^{19}$ The activation of carcinogens is primarily catalyzed by phase I enzymes, protection may be accomplished by inhibition of activating enzymes and/or by induction of phase II enzymes which leads to detoxification and accelerated excretion of carcinogens. $^{20}$ Hence, both phase 1 enzyme (GPx) and phase II enzyme (GST) have been considered in present study.

Ample biomarkers existing for assessing genotoxicity, which is often measured as the representative of cancer.

\section{REFERENCES}

1. Hattemer-Frey HA, Travis CC, Benzo[a]pyrene: Environmental partitioning and human exposure, Toxicology and Industrial Health, 1991; 7(3)"141-157.

2. Billiard SM, Meyer JN, Wassenberg DM, Hodson PV, Di Giulio RT, Non-additive effects of PAH on early vertebrate development: Mechanisms and implications for risk assessment, Toxicological Science, 2008; 105(1):5-23.

3. Curtis LR, Garzon CB, Arkoosh M, et al., Reduced Cytochrome P4501A activity and recovery from oxidative stress during subchronic benzo[a]pyrene and benzo[e]pyrene treatment of rainbow trout, Toxicology and Applied Pharmacology, 2011; 254(1):1-7.

4. Archibong AE, Ramesh A, Niaz MS, Brooks CM, Roberson SI, Lunstra DD, Effects of benzo(a)pyrene on intra-testicular function in F-344 rats, International Journal of Environmental Research and Public Health. 2008; 5(1):3240.

5. Valentovic MA, Alejandro N, Carpenter AB, Brown PI, Ramos K, Streptozotocin (STZ) diabetes enhances benzo(a)pyrene induced renal injury in Sprague Dawley rats, Toxicological Letters, 2006; 164(3):214-220.

6. Nanez A, Alejandro NF, Falahatpisheh M, Kerzee JK, Roths JB, Ramos KS, Disruption of glomerular cell-cell and cellmatrix interactions in hydrocarbon nephropathy, American Journal of Renal Physiology 2005; 289(6):F1291-F1303.

7. Jahangir T, Safhi MM, Sultana S, Ahmad S, Pluchea lanceolate protects against Benzo(a) pyrene induced renal toxicity and loss of DNA integrity, Interdisciplinary Toxicology, 2013; 6(1):47-54.
Previous studies indicate that that $\mathrm{B}(\mathrm{a}) \mathrm{P}$ treatment leads to genotoxicity, chromosomal abbreviations, micronuclei induction, DNA adduct formation, strand breaks, etc. in a rodent model of experiment. ${ }^{15}$ It is evident from this study that mangiferin was suppressed the formation of micronuclei polychlorinated erythrocytes in vivo, which are the hallmarks of $\mathrm{B}(\mathrm{a}) \mathrm{P}$ induced genotoxicity. ${ }^{7}$ Mouse bone marrow micronucleus assay is a widely used genotoxic assay to detect both clastogenic and aneugenic potencies of genotoxic agents or radiation. ${ }^{21}$ Chromosomal modifications with development of micronuclei may serve as an effective biomarker to assess cancer risk. This study revealed an increased number of micronuclei in PCE in comparison with the control group indicating that $\mathrm{B}(\mathrm{a}) \mathrm{P}$ produces chromosomal damage in erythrocytes of bone marrow and this damage is associated with the appearance and/or progression of tumors with adverse reproductive and developmental outcomes. These changes are in agreement with previous studies. ${ }^{22}$ In present study, it is evident from the results that mangiferin reduced the number of micronuclei in comparison with the $\mathrm{B}(\mathrm{a}) \mathrm{P}$ toxic group.

In conclusion, mangiferin amelioration of B(a)P-induced renal toxicity is attributed to the enhancement antioxidant defense mechanism and improvement in the genotoxic procedure. Thus, supplementation and/or treatment with mangiferin could exert protective effects against renal toxicity resulting from $\mathrm{B}(\mathrm{a}) \mathrm{P}$ exposure. However, further studies are required in order to gain more insight at molecular level.

8. Steinmetz KA, Potter JD, Vegetables, fruits and cancer. I. Epidemiology, Cancer Causes Control, 1991; 2(5):325-57.

9. Sanugul, K, Akao T, Li Y, Kakiuchi N, Nakamura $\mathrm{N}$ et al., Isolation of a human intestinal bacterium that transforms mangiferin to norathyriol and inducibility of the enzyme that cleaves a C-glucosyl bond. Biological and Pharmaceutical Bulletin, 2005; 28(9):1672-1678.

10. Matkowski A, Kus P, Góralska E, Wozniak D, Mangiferin a bioactive xanthonoid, not only from mango and not just antioxidant, Mini Reviews in Medicinal Chemistry, 2013; 13(3):439-55.

11. Prabhu S, Jainu M, Sabitha KE, Devi CSS, Cardioprotective effect of mangiferin on isoproterenol induced myocardial infarction in rats, Indian Journal of Experimental Biology, 2006; 44(3):209e15.

12. Athar $\mathrm{M}$, Iqbal $\mathrm{M}$, Ferric nitrilotriacetate promotes $\mathrm{N}$ diethylnitrosamine- induced renal tumorigenesis in the rat: Implications for the involvement of oxidative stress, Carcinogenesis, 1998; 19(6):1133-1139.

13. Mohandas J, Marshall JJ, Duggin GG, Horvath JS, Tiller DJ, Low activities of glutathione related enzymes as factors in the genesis of urinary bladder cancer, Cancer Research, 1984; 44(11):5086-5091.

14. Habig WH, Pubst MJ, Jokoby WB, GST the first enzymatic step in mercapturic acid formation, Journal of Biological Chemistry, 1974; 249(22):7130-7139.

15. Khan TH, Prasad L, Anuradha, Sultana S, Soy isoflavones inhibit the genotoxicity of benzo(a)pyrene in Swiss albino mice, Human Experimental Toxicology, 2005; 24(3):149155. 
16. Shugart LR, Quantitation of chemically induced damage to DNA of aquatic organisms by alkaline unwinding assay, Aquatic Toxicology, 1988; 13(1):43-52.

17. Schimd W, The micronucleus test, Mutation Research, 1975; 31(1):1-9.

18. Qamar W, Khan AQ, Khan R et al., Benzo(a)pyrene-induced pulmonary inflammation, edema, surfactant dysfunction, and injuries in rats: Alleviation by farnesol, Experimental Lung Research, 2012; 38(1):19-27.

19. Garner RC, The role of DNA adducts in chemical carcinogenesis, Mutation Research, 1998; 402(1-2); 67-75.

20. Prochaska $\mathrm{HJ}$ and Talalay $\mathrm{P}$, Regulatory mechanisms of monofunctional and bifunctional anticarcinogenic enzyme inducers in murine liver, Cancer Research, 1988; 48(17):4776-4782.

21. Ramalho AT, Nascimento AH, Littlefi eld LG, Natarajan AT, Sasaki MS, Frequency of chromosomal aberrations in a subject accidentally exposed to $137 \mathrm{Cs}$ in the Gorania(Brazil) radiation accident: Inter comparison among four laboratories. Mutation Research and Environ Mutagen, 1991; 252(2); $157-160$.

22. Krishna G, Hayashi M, In vivo rodent micronucleus assay: Protocol, conduct and data interpretation, Mutation Research, 2000; 455(1-2):155-166. 